\title{
Role of diagnostic laparoscopy in penetrating anterior abdominal wall trauma
}

\author{
David Parizh, Vadim Meytes, Anthony Kopatsis
}

Department of General Surgery, NYU Lutheran, Brooklyn, New York, USA

\section{Correspondence to}

Dr David Parizh,

david.parizh@nyumc.org

Accepted 3 October 2016

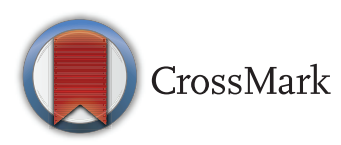

To cite: Parizh D, Meytes V, Kopatsis A. BMJ Case Rep Published online: [please include Day Month Year] doi:10.1136/bcr-2016217646

\section{DESCRIPTION}

A man aged 38 years who underwent assault, presented with a stab wound to the anterior abdomen, LLQ (figure 1A). He was haemodynamically stable, no peritoneal signs on abdominal examination, FAST and local wound explorations were inconclusive. CT scan of the abdomen/pelvis did not show any obvious evidence of small bowel injury (figure 1B). Owing to the proximity of the small bowel to the abdominal wall, the patient was admitted and monitored for delayed diagnosis and injury in our level I trauma centre. Over the next 6 hours, the patient gradually became more tachycardic, with mild abdominal distension. Emergent diagnostic laparoscopy was performed, yielding a knuckle of small bowel protruding into the abdominal wall (figure 1C) and an enterotomy in the distal jejunum (figure 1D), which was resected and a primary anastomosis was performed.

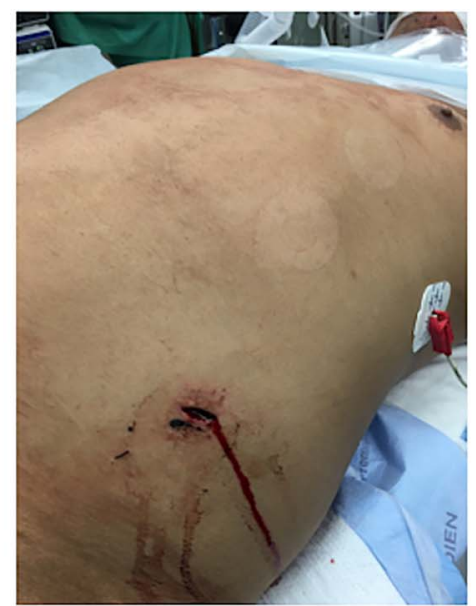

A. Stab wound to LLQ Anterior Abdominal Wall

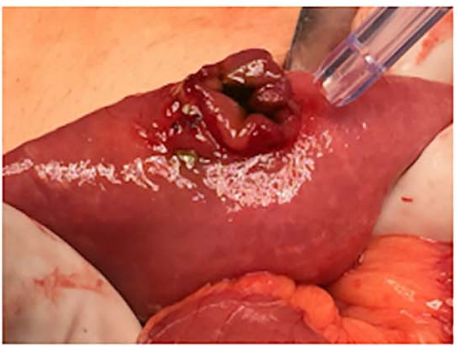

D. Jejunal Enterotomy

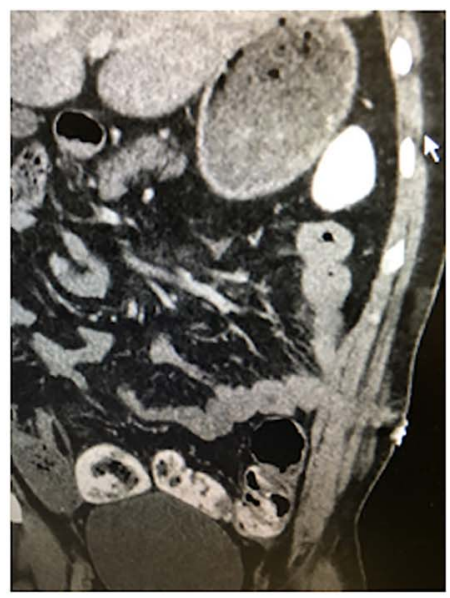

B. CT ABD/Pelvis Figure 1 Note the LLQ abdominal stab wound seen (A) that failed to show any signs of eviscerations of fascia
violation on examination. CT ABD/pelvis (B) shows the small bowel abutting the abdominal wall, close examination
shows the abdominal wall haematoma, and in hindsight evidence to raise suspicion for bowel injury and evisceration
(C) Diagnostic laparoscopy confirms fascial violation and small bowel enterotomy (D). Figure 1 Note the LLQ abdominal stab wound seen (A) that failed to show any signs of eviscerations of fascia
violation on examination. CT ABD/pelvis (B) shows the small bowel abutting the abdominal wall, close examination
shows the abdominal wall haematoma, and in hindsight evidence to raise suspicion for bowel injury and evisceration
(C) Diagnostic laparoscopy confirms fascial violation and small bowel enterotomy (D). Figure 1 Note the LLQ abdominal stab wound seen (A) that failed to show any signs of eviscerations of fascia
violation on examination. CT ABD/pelvis (B) shows the small bowel abutting the abdominal wall, close examination
shows the abdominal wall haematoma, and in hindsight evidence to raise suspicion for bowel injury and evisceration.
(C) Diagnostic laparoscopy confirms fascial violation and small bowel enterotomy (D). Figure 1 Note the LLQ abdominal stab wound seen (A) that failed to show any signs of eviscerations of fascia
violation on examination. CT ABD/pelvis (B) shows the small bowel abutting the abdominal wall, close examination
shows the abdominal wall haematoma, and in hindsight evidence to raise suspicion for bowel injury and evisceration
(C) Diagnostic laparoscopy confirms fascial violation and small bowel enterotomy (D).

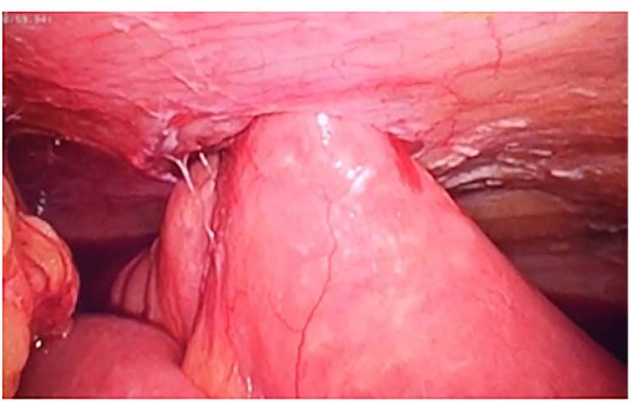

C. Evicerated small bowel 


\section{Learning points}

- A management algorithm for anterior abdominal wall stab wounds has evolved over the years from conservative management which were managed non-operatively in the 19th century to mandatory laparotomy during World War I. Pendulum swung the other way in the 1960 s to decrease the rate of negative abdominal explorations and morbidity associated with a laparotomy. Over the years, algorithms to better select patient population who can benefit most from mandatory exploration have been refined. ${ }^{1}$

- The Eastern Association for the Surgery of Trauma currently recommends as a level 1 recommendation that non-operative management (eg, local wound exploration examining defects in fascia, diagnostic peritoneal lavage, FAST ultrasound examination, CT imaging and serial abdominal examination) are best suited for patients who are haemodynamically stable without overt signs of peritonitis. $^{23}$

- Laparoscopic surgery is clearly becoming common practice as surgeons are progressing along the learning curve. We anticipate incorporation of laparoscopic techniques early on in the management algorithm of anterior abdominal wall stab wounds as they become second nature and incorporate into the evolving armamentarium of the minimally invasive trauma surgeon.
Contributors The following is a breakdown of each author's contributions: DP is responsible for the conception and design of the research study, acquired data, analysis and interpretation of data, drafting the article, revising intellectual content, final approval of the version to be published. VM is responsible for the conception and design of the research study, acquired data, analysis and interpretation of data, drafting the article, revising intellectual content, final approval of the version to be published. AK is responsible for the conception and design of the research study, acquired data, analysis and interpretation of data, drafting the article, revising intellectual content, final approval of the version to be published.

Competing interests None declared.

Patient consent Obtained.

Provenance and peer review Not commissioned; externally peer reviewed.

\section{REFERENCES}

1 Pruitt BA. Combat casualty care and surgical progress. Ann Surg 2006;243:715-29.

2 Como JJ, Bokhari F, Chiu WC, et al. Practice management guidelines for selective nonoperative management of penetrating abdominal trauma. J Trauma 2010;68:721-33.

3 Sumislawski JJ, Zarzaur BL, Paulus EM, et al. Diagnostic laparoscopy after anterior abdominal stab wounds: worth another look? J Trauma Acute Care Surg 2013;75:1013-17; discussion 1017-18.

Copyright 2016 BMJ Publishing Group. All rights reserved. For permission to reuse any of this content visit http://group.bmj.com/group/rights-licensing/permissions.

BMJ Case Report Fellows may re-use this article for personal use and teaching without any further permission.

Become a Fellow of BMJ Case Reports today and you can:

- Submit as many cases as you like

- Enjoy fast sympathetic peer review and rapid publication of accepted articles

- Access all the published articles

- Re-use any of the published material for personal use and teaching without further permission

For information on Institutional Fellowships contact consortiasales@bmjgroup.com

Visit casereports.bmj.com for more articles like this and to become a Fellow 